\title{
Design of Flood Warning System Based loT and Water Characteristics
}

\author{
Herman Yuliandoko', Subono' 2 Vivien Arief Wardhany ${ }^{3}$, Sholeh Hadi Pramono ${ }^{4}$, \\ Ponco Siwindarto ${ }^{5}$ \\ 1,2,3 Labanasem Banyuwangi East Java-Indonesia, Informatic Engineering Dept. State, \\ Polytechnic of Banyuwangi, Indonesia \\ ${ }^{4,5}$ Malang East Java-Indonesia, Electrical Engineering Dept. Brawijaya University, Indonesia \\ *Corresponding author, e-mail: herman.yuliandoko@poliwangi.ac.id', subono@poliwangi.ac.id ${ }^{2}$, \\ vivien.wardhany@poliwangi.ac.id ${ }^{3}$, Sholehpramono@ub.ac.id ${ }^{4}$, ponco@ub.ac.id ${ }^{5}$
}

\begin{abstract}
Indonesia is one of the tropical country with high rainfall. It causes a flood disaster that with the loss of property and life. Currently handling flood disasters in developing countries are still using many conventional ways. By using conventional way the flood early warning system is still not able to reach the wider community so that information too late of impending disaster received by the public. Besides that the speed of information is needed in the handling of disasters. Therefore a rapid flood warning system that can reach a wide area such as the internet is necessary to minimize the effects of disasters. IoT (Internet of Thing) is smart technology which has capability to send data in real time, connected to the smart phone, sensor and web service. This ability can be used for smart application to control and manage an early warning system. In this research we also use IoT technology to monitor and control the early detection system of flood disaster. By using loT technology, sensor data can be sent in real time from sensor to smartphone through internet network. The sensor data contains the water characteristics data on the dam that will be processed in the data base. The processing data of water characteristic will be a decision of hazard level. That decision will be sent to users as notification into the user smartphone application. This research will be useful for deeply research on disaster management system and flood early detection system in Indonesia.
\end{abstract}

Keyworld: flood, IoT, sensor, application, dam

Copyright $\odot 2018$ Universitas Ahmad Dahlan. All rights reserved.

\section{Introduction}

Indonesia is an archipelago with thousands of islands that stretches from Sabang to Merauke. Indonesia also has a geographical area within the boundaries of the three major slabs of the Indo-Australian, Pacific, and Eurasian plates that are potentially earthquakes if changes occur in the plates. Besides, Indonesia is also located in the confluence of three mountain systems namely Circum-Pacific, Sunda Alpine and Circum Australia, which is the path most active volcano in the world series. Indonesia has approximately 240 volcanoes with $70 \%$ of them still active [1]. These conditions make Indonesia a region with high disaster-prone.

Based on above data show that flooding is highest natural disaster in Indonesia and it causes a lot of loss of property and life. Disaster management is very important as well as for Indonesia. But the problem is the majority disaster management in Indonesia still use traditional way. It is also in the Banyuwangi, East Java, Indonesia. Disaster detection in Banyuwangi based on visual monitoring on DAM, in the every DAM in Banyuwangi have a foreman who always monitor and make report the water condition on DAM. This conventional method is not simple and the foreman has to stay in the location 24 hours and it is very difficult to make sure the foreman 24 hours on the position. In another side the warning information of disaster must be sent in quickly and accurate to people so that the early warning can prevent high loss of property and life. Natural Disaster in Indonesia [2] as shown in Figure 1.

Flooding is become highest problem of natural disaster in Indonesia. Therefore research in this area will be useful and many researchers have done research in this field. Elizabet and Daniela in "Design of Early Warning Flood Detection Systems for Developing Countries", made a research design in Honduras about warning system on river flooding [3]. In their research they found that Developing countries experience much worse havoc than 
developed, however, and are less equipped to deal with the aftereffects of these disasters. Their research focused on management of early warning system of river flooding but they did not explain detail mechanism of early warning system.

\section{The Number of Natural Disaster in Indonesia}

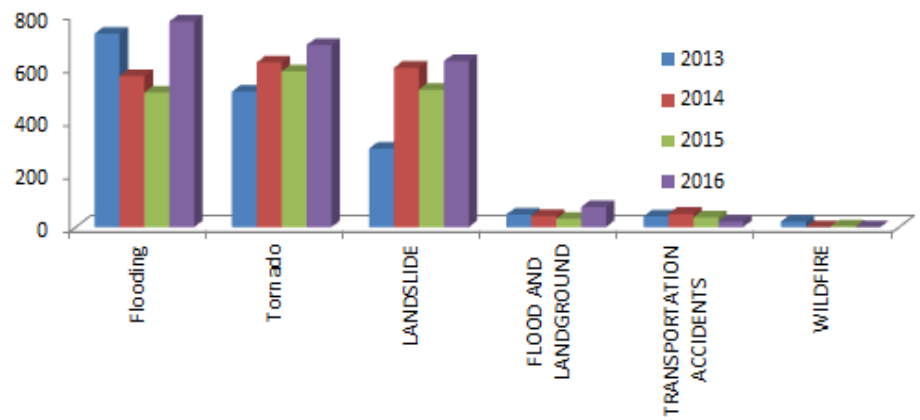

Figure 1. Natural Disaster in Indonesia [2]

There is some mechanism for detecting flooding. In the "Flash Flood Detection in Urban Cities Using Ultrasonic and Infrared Sensors", the flooding detection was using ultrasonic and infrared sensors [4]. This research presented to contribute to the literature of flash flood sensing using a custom-designed sensor comprising an ultrasonic rangefinder and multiple passive infrared temperature sensors. Flood monitoring and detection also done by using wireless sensor network [5], this research design flood monitoring and detection system using water level, amount of rainfall, relative humidity and temperature as monitored variables for flood detection. The relative humidity and temperature values are used to monitor the rate of rainfall. The amount of rainfall values are used to predict the water level. The water level will determine the extent of the flood as low, medium or high. This will enhance early flood detection. The flood status is sent directly to the occupants of the flood prone region directly from the surveillance Centre. But in the both of detection system the data was sent without internet network and smartphone application on end user. It made covering area and user mobility was limited.

The flood monitoring research which use loT (Internet of Thing) also done on An "Internet of Thing" Vision of the Flood Monitoring Problem [6]. This research makes a study of literature the opportunity to make flood detection by using loT through rain gauging and river gauging. They also presented the gauge shielding architecture and software requirement for loT implementation. Therefore this research need to improve with next step study on simulated and real time scenarios, and an implementation of the software behavior loT platforms.

Mahendra Salunke and Nilesh Korade on "Survey on Flooding Detection System using Internet of Things" also make a flooding detection research [7]. Their research described the literature survey the application of Internet of Things in urban management flooding prevention management system. The architecture of flooding detection system divided in to three dimension, calculation of drainage flow, rainfall, and water level, second sending collected flooding information to data center for analysis and monitoring and alerting mechanism. This research also analysis the sensor components needed, the ultrasonic flow meter used for measures the velocity of a fluid with ultrasound to calculate volume flow, water level indicator sensor used for determine water level from ground, rain sensor to detect the velocity of rainfall.

In flooding detection system there are two main important factors, precision of flooding detection and speed of information handling. The precision of flooding detection is important because this factor to make sure that information of flooding is true and it can be referent for people to follow up the information for advance actions. To minimize of flooding effect of disaster the rapid of early warning for flooding disaster to give the people time for save their property and life is very important. That why in our research we are focused on the accuracy of information and speed of information can reach on wide area. The characteristic of water on dam can be referent to make a decision that flooding is occurring on dam. Water characteristic is a condition where changes in water level and water velocity on the dam really make sure that 
floods will occur instead of pseudo or temporary changes. Our research also use internet to send flooding information quickly and reach wide area. That is different with another research which only use water level to detect flooding without combine with another sensor to make sure the data is accurate and send quickly by using internet.

\section{Material and Methods}

\subsection{Preparation of microcontroller}

The ESP-8266 is a microcontroller which it is in the beginning build by developers' Chinese origin "Espressif". This microcontroller become a new interesting tool in loT because have good ability to connect to internet. The ESP-8266 also have onboard wifi module as shown in Figure 2, cheap and SoC (System on Chip) so it can be programmed without any additional microcontroller. In this research ESP-8266 connected directly to the water level sensor and water velocity sensor. loT (Internet of Things) connects all goods with internet. There are many application of loT and today become a big thing in the world. IoT is not only a network also a system which connects all living articels with internet to form a larger network $[8,9]$.

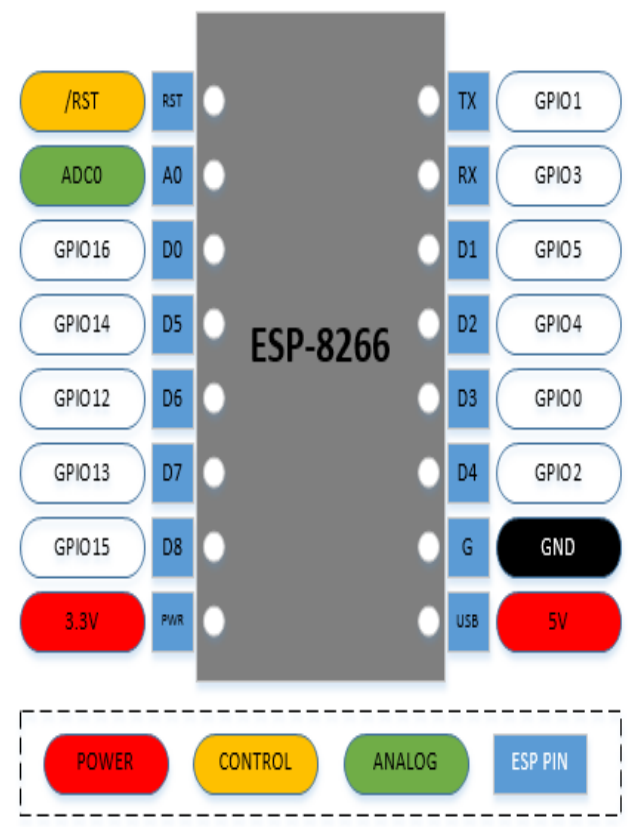

\begin{tabular}{|c|c|c|}
\hline Pin & Function & ESP-8266 Pin \\
\hline TX & TXD & TXD \\
\hline RX & RXD & RXD \\
\hline A0 & Analog input, max 3.3V input & A0 \\
\hline D0 & IO & GPIO16 \\
\hline D1 & IO, SCL & GPIO5 \\
\hline D2 & IO, SDA & GPIO4 \\
\hline D3 & IO,10k Pull-up & GPIO0 \\
\hline D4 & IO, 10k pull-up, BUILTIN_LED & GPIO2 \\
\hline D5 & IO, SCK & GPIO14 \\
\hline D6 & IO, MISO & GPIO12 \\
\hline D7 & IO, MOSI & GPIO13 \\
\hline D8 & IO,10k pull-down, SS & GPIO15 \\
\hline G & Ground & GND \\
\hline 5V & 5V & - \\
\hline 3V3 & 3.3V & $3.3 \mathrm{~V}$ \\
\hline RST & Reset & RST \\
\hline
\end{tabular}

Figure 2. ESP-8266 Block Diagram

\subsection{Preparation of sensor}

The sensor of water level used to detect characteristic of water on dam. The water characteristic is a water condition on the dam which it is indicating that flooding has occurred. The water characteristic also want to check that the changing of water is only a temporary change that does not result in flooding. This characteristic very important to make sure that our flooding prediction is a precise prediction. To know water characteristic we use multiple sensors to detect water level on dam.

\subsubsection{Ultrasonic sensor}

Ultrasonic sensor in this research used to detect water level condition. This sensor works by emitting ultrasonic waves and receive the signal reflected by an object. Delay time between transmitted and received ultrasonic wave can be analyzed to know the distance between sensors with object. Ultrasonic working theory [10] as shown in Figure 3. 


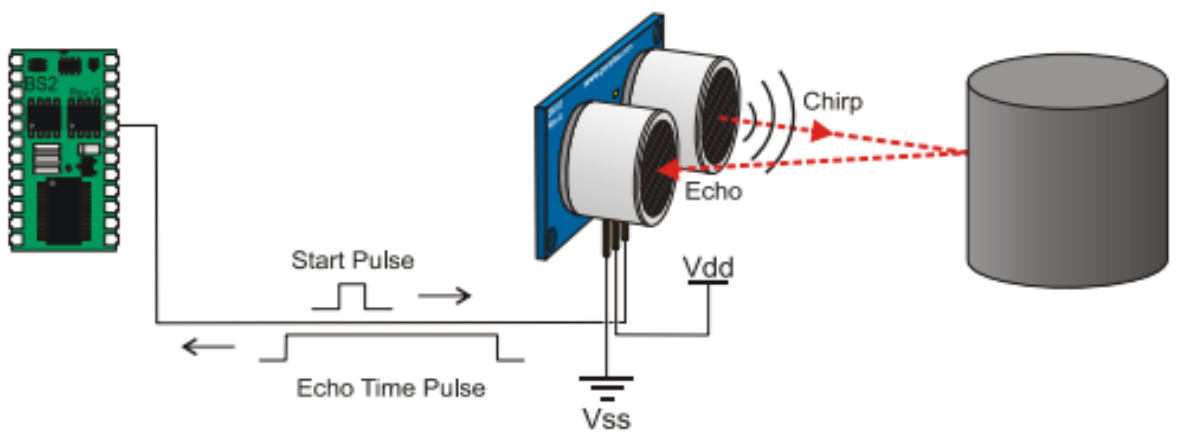

Figure 3. Ultrasonic working theory [10]

This sensor transmit ultrasonic wave for $200 \mu \mathrm{s}$ and then detect the reflection wave. Ultrasonic wave spread in the air with the velocity about $344 \mathrm{~m} / \mathrm{s}$ (sound wave velocity), touch the object and reflected back to the sensor. That mechanism is used ultrasonic to measure the distance as below [11]:

$$
\mathrm{S}=\left(\mathrm{t}_{\mathrm{IN}} \times \mathrm{V}\right) \div 2
$$

where,

$\mathrm{S}=$ the distance between ultrasonic with object detected

$\mathrm{V}=$ sound wave velocity

$\mathrm{t}_{\mathrm{N}}=$ time deviation wave transmit and receive

To measure water level on dam through reduce the height of the sensor with the height of calculating the distance of the sensor to the object (water). Reading Water Level (WS) as shown in Figure 4.
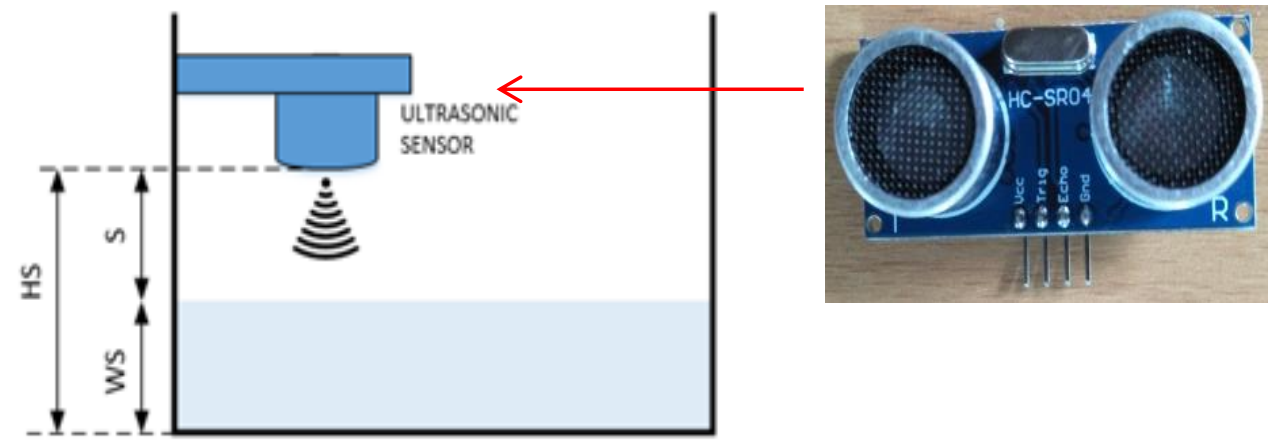

Figure 4. Reading Water Level (WS)

$$
\text { WS }=\text { HS }-S
$$

where,

$\mathrm{S}=$ the distance between ultrasonic with object detected

$\mathrm{HS}=$ Sensor High

WS=Water High (water level)

\subsubsection{Water velocity sensor}

In the flood monitoring system, the water velocity monitoring is also important to monitor and inform because it will affect to the dam capacity. There is any sensor mechanism of liquid flow and Hall Effect sensor is one of liquid flow sensor type. Hall Effect sensor is a transducer 
that varies its output voltage in response to a magnetic field. This sensor is the production of a voltage difference across an electrical conductor, transverse to an electric current in the conductor and a magnetic field perpendicular to the current. Water flow sensor, arduino and sircuit diagram [12] as shown in Figure 5.
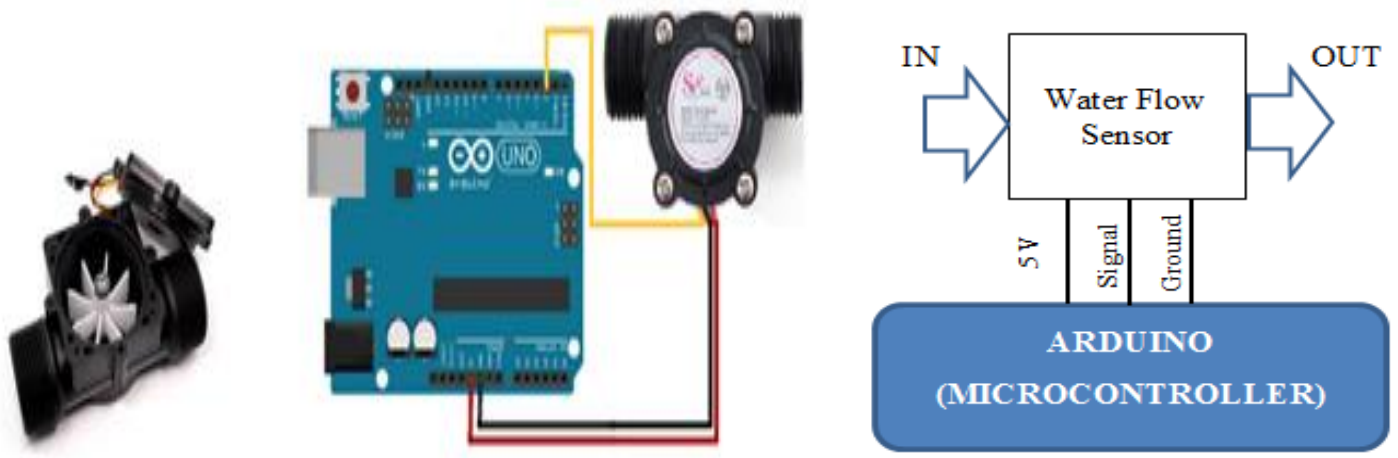

Figure 5. Water flow sensor, arduino and sircuit diagram [12]

This sensor consists of several parts of plastic valve, water rotor and hall effect sensor. When water flows through the rotor, the rotor will rotate. The speed rotation of the rotor depends on water flow on the valve. The hall effect sensor will produce pulse similar to the quantity of water flow. To find out of the water flow volume (liter) can be calculated as below

$$
Q=\text { (the quantity of pulse for an hours) } x \frac{60}{7,5}
$$

\subsubsection{ESP8266 and sensor circuit}

To monitor water characteristic, it is important to make sure the circuit between ESP8266 with sensors is correct. Each sensor in this research use power which it is integrated with ESP8266 on 3.3 Volt DC. First ultrasonic sensor connected to ESP8266 pin no D6 (GPIO12) and D7 (GPIO13) for the input output, second ultrasonic sensor connected to the pin D1 (GPIO5) and D2 (GPIO4). While the water velocity sensor connected to pin D3 (GPIO0). That all of circuit can be found as Figure 6 .

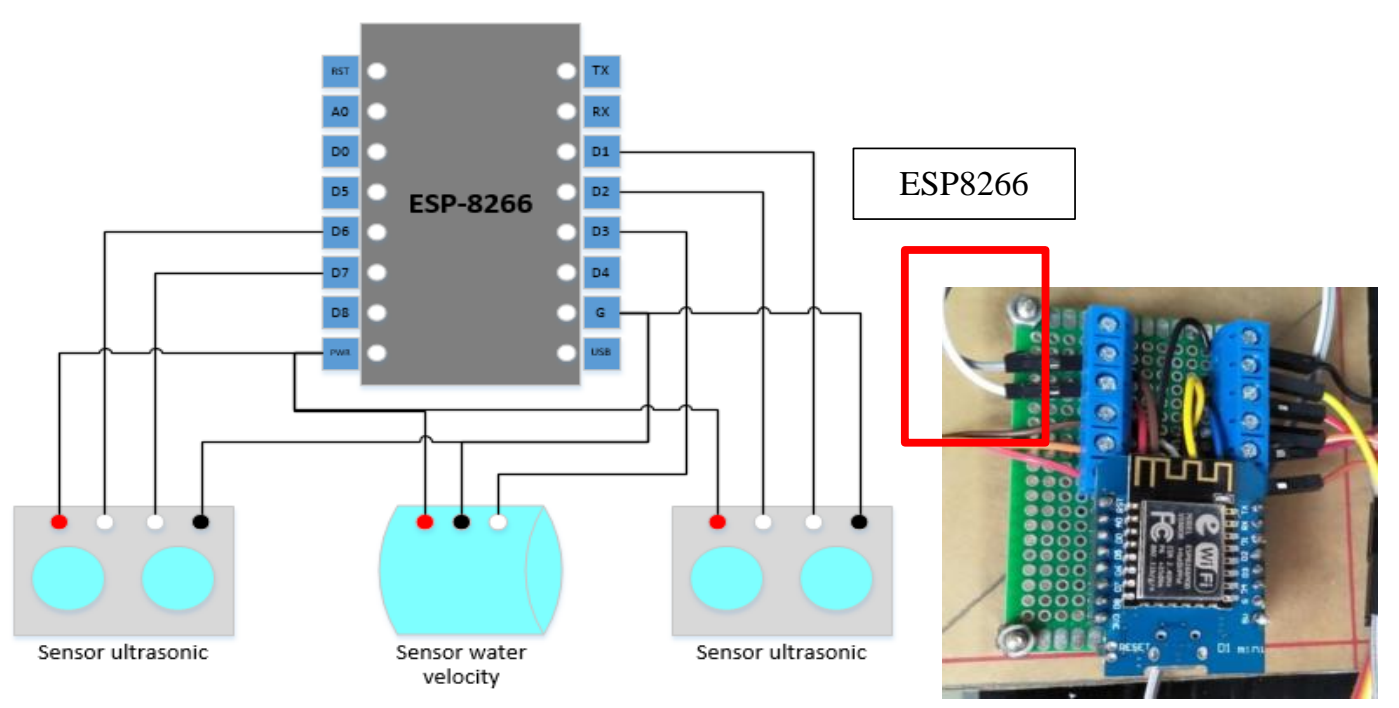

Figure 6. Circuit of ESP8266 to the sensors 


\subsection{Preparation of dam prototype}

This research use prototype of dam to make any scenario of experiment and the scenario is made to presenting of water characteristic as same as on real dam condition. The prototype of dam is built from acrylic and added with sensors as Figure 7. The sensors in the dam are used to inform the characteristic of water, two sensors ultrasonic and one velocity of water. First sensor ultrasonic on the downstream river prototype with high of sensor is $8 \mathrm{~cm}$ from bottom, and second ultrasonic sensor on the dam with high of sensor is $10 \mathrm{~cm}$.

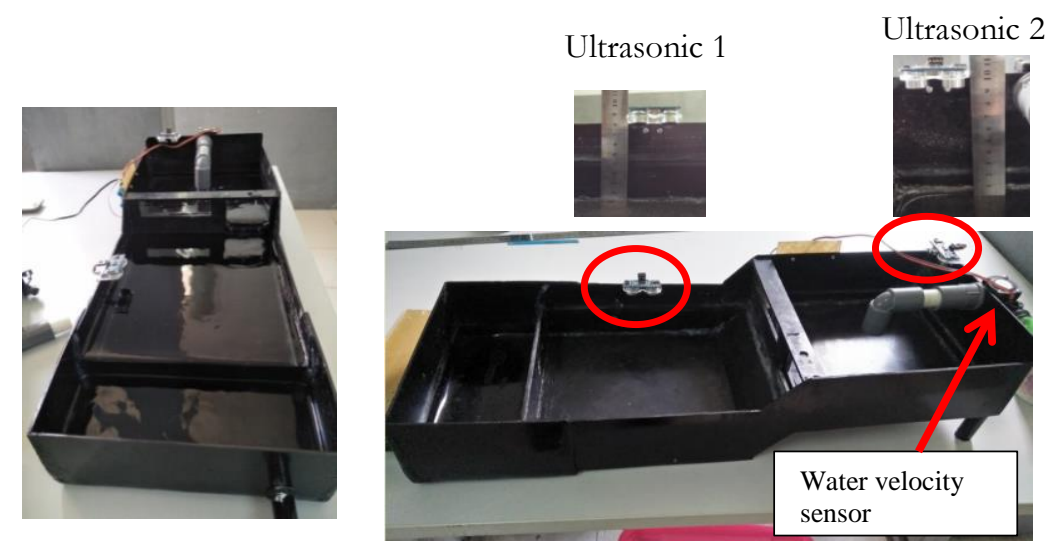

Figure 7. Dam prototype with sensors

\section{Software Programing}

There are three software programing in this paper, first programing in the ESP8226, second on the web server and third on the android application. But to read water characteristic software programing on ESP8266 is very important because it can receive data through this programming. Programing for water level and water velocity as shown in Figure 8.

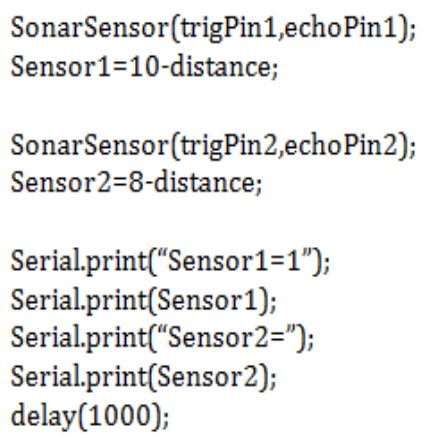

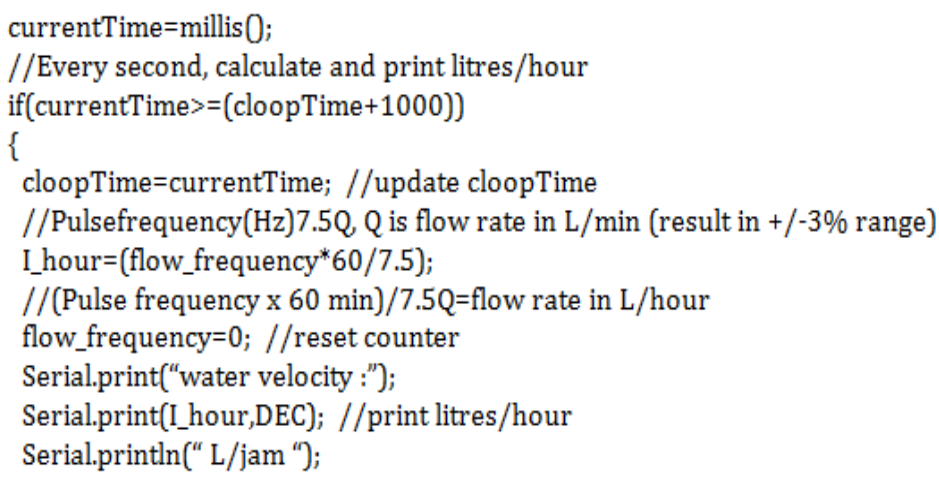

Figure 8. Programing for water level and water velocity

\section{Experiment Sensors}

In this research we will make experiment with any scenarios, these all scenarios is make to represent real condition in dam during flooding.

a. First experiment, all of gate on the normal flow and the condition of the water level is stable.

b. The second scenario is the water characteristic at the high dam by closing the dam gate and downstream of the prototype under normal conditions. The purpose of the second experiment is to show that if the water level characteristics of the dam are high then it is not certain there has been a flood. 
c. Third scenario is water characteristic on downstream is high but low on the dam. The purpose of this scenario is to check that the flooding is not only influence by water characteristic on downstream.

d. The last scenario is the water characteristic on dam and downstream are high condition and we want to know that flooding occur is related with water characteristic on dam and downstream. Rule of characteristic water result as shown in Figure 9.

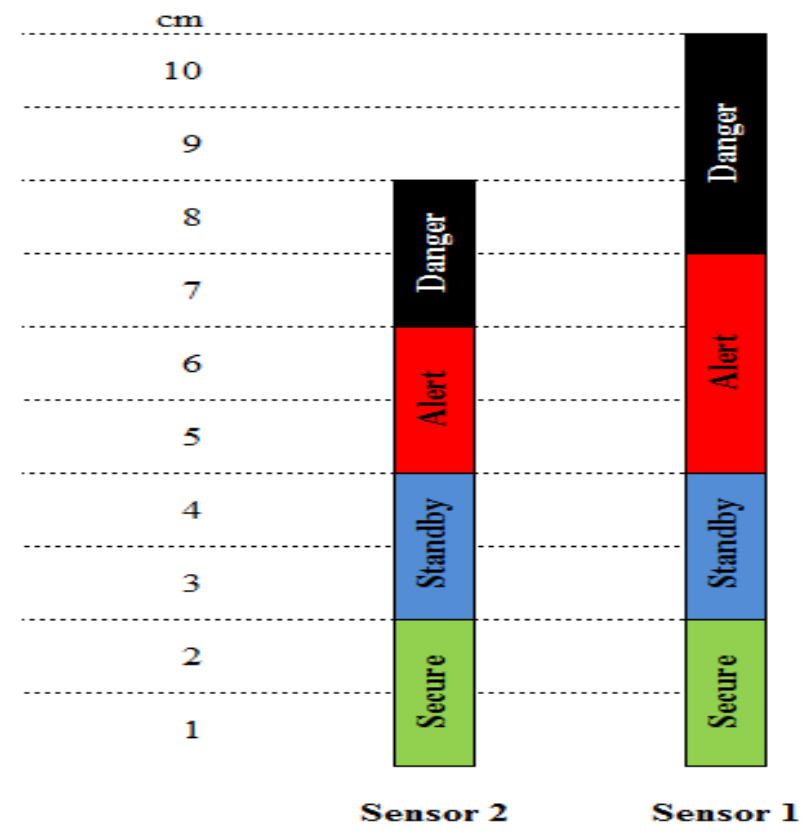

\begin{tabular}{|c|c|c|}
\hline Sensor 1 & Sensor 2 & Result \\
\hline Secure & Secure & Secure \\
\hline Secure & Standby & Secure \\
\hline Secure & Alert & Secure \\
\hline Secure & Danger & Secure \\
\hline Standby & Secure & Secure \\
\hline Standby & Standby & Standby \\
\hline Standby & Alert & Standby \\
\hline Standby & Danger & Standby \\
\hline Alert & Secure & Secure \\
\hline Alert & Standby & Standby \\
\hline Alert & Alert & Alert \\
\hline Alert & Danger & Alert \\
\hline Danger & Secure & Secure \\
\hline Danger & Standby & Standby \\
\hline Danger & Alert & Alert \\
\hline Danger & Danger & Danger \\
\hline
\end{tabular}

Figure 9. Rule of Characteristic Water Result

Figure 10 show that sensor can detect the characteristic of water on dam and downstream river. In this system is not only detect the characteristic of water but it is also make a decision about status of flooding. The Level status of flooding is divided in the four level, secure, standby, alert and danger. Level secure is a condition of no flooding and safe for people in the location. Second level is standby, this level is representative that the status of water characteristic still in safe condition but in standby position. Alert level is a condition that people should take attention that water is not safe anymore and have to prepare for any aspect from flooding. The last level is danger, this level is the top level of water condition and need evacuation from flooding location. 

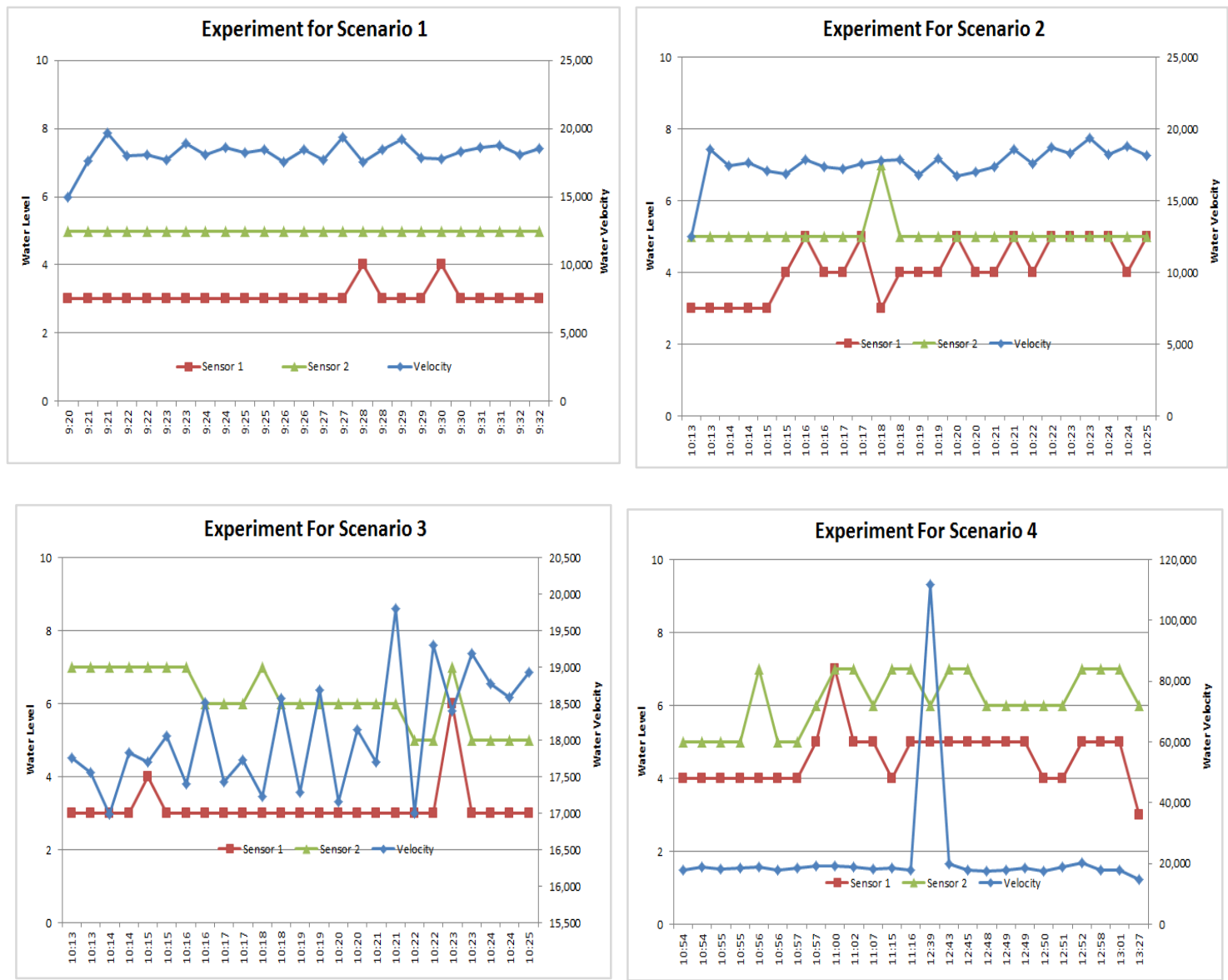

Figure 10. Graphic of Water Characteristic

\section{Web services and Notification}

This research also added with location or map of dam, so that by using this system can monitor more than one dam. The monitoring system on dams will useful for make sure flooding mapping in the city. By using internet the real time monitoring and monitoring for any dams can inform to the people about flooding fastest and accurate. Web monitoring of water condition as shown in Figure 11.
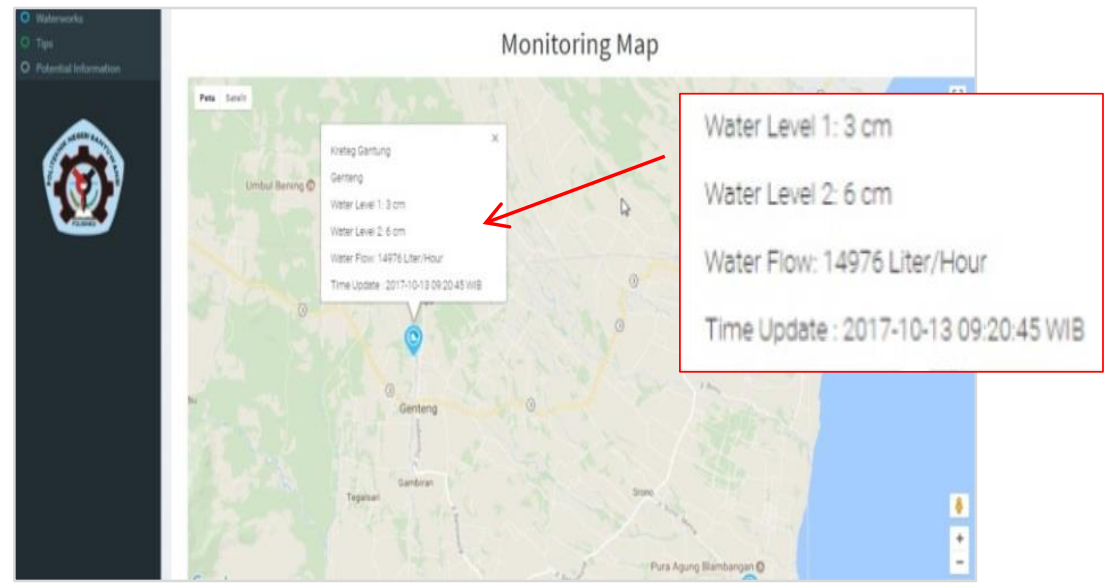

Figure 11. Web Monitoring of Water Condition 
The notification of dam status sends in real time to the web service and flooding early warning application. In the our early warning application also can monitor the status on graphics and give alert sound if there is alert or danger dam status. By using this application people will get information about dam in real time. Flow of notification and flooding alert application and application and status level notification as shown in Figure 12 and Figure 13.

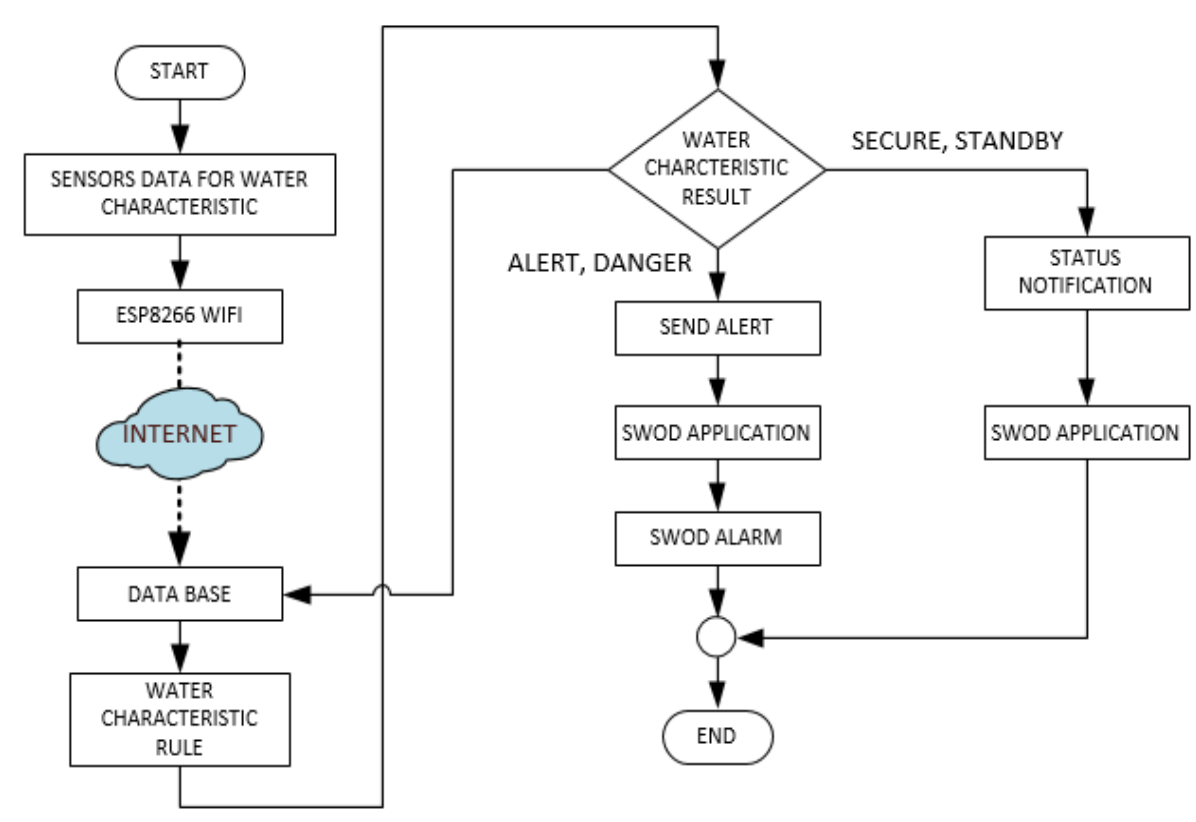

Figure 12. Flow of Notification and Flooding Alert Application

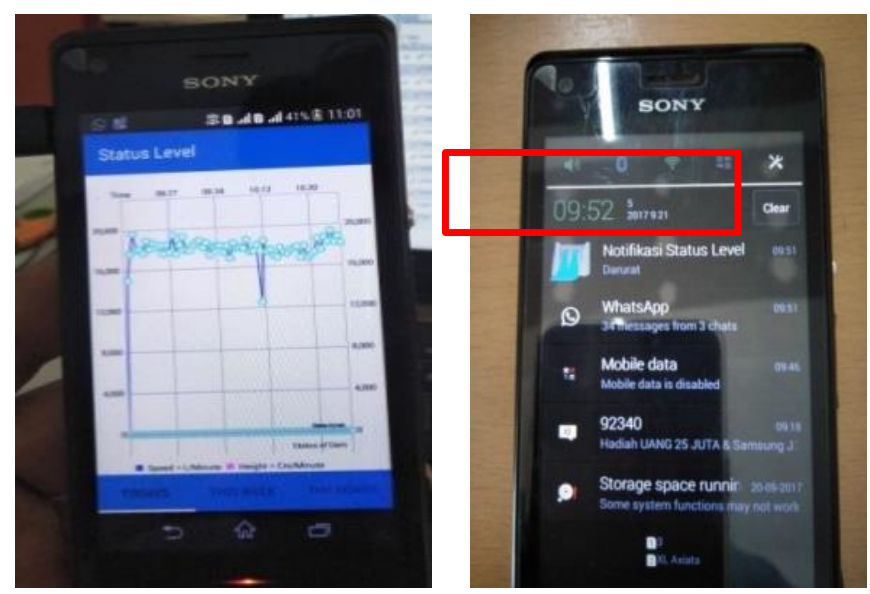

Figure 13. Application and Status Level Notification

\section{Conclusion}

Flooding warning system based on Internet of Thing is very interesting one, because by using this technology we can prevent many loss of property or life. This research has represented an effective system detection of flooding with smart phone application and internet to speed up flooding information to the people. This research also prove that water characteristic can be came an important parameter for flooding warning information. Although the quantity of sensor will be influence to the accuration of detection. In the next research the quantity of sensor need to be added to get more accurate data of flooding. 


\section{References}

[1] L Tondobala. Pemahaman Tentang Kawasan Rawan Bencana dan Tinjauan Terhadap Kebijaksanaan dan Peraturan Terkait. Jurnal Sabua. 2011; 3: 58-63.

[2] BNPB (Badan Nasional Penanggulangan. Data bencana 2017. 2017.

[3] E Basha, D Rus. Design of Early Warning Flood Detection Systems for Developing Countries. International Conference on Information and Communication Technologies and Development. 2007.

[4] M Mousa, X Zhang, C Claudel. Flash Flood Detection in Urban Cities Using Ultrasonic and Infrared Sensors. IEEE Sensors Journal. 2016.

[5] EN Udo, EB Isong. Flood Monitoring and Detection System using Wireless Sensor Network. Asian Journal of Computer and Information Systems. 2013; 1(04): 108-113.

[6] M Ancona, A Dellacasa, G Delzanno, AL Camera, I Rellini. An "Internet of Thing" Vision of the Flood Monitoring Problem. AMBIENT 2015: The Fifth International Conference on Ambient Computing, Applications, Services and Technologies. 2015: 26-29.

[7] M Salunke, N Korade. Survey on Flooding Detection System using Internet of Things. International Journal of Computer Applications. 2017; 165.

[8] X Bing. Key Internet of Things Technology and Application. TELKOMNIKA Indonesian Journal of Electrical Engineering. 2014; 12(7).

[9] L Hua, Z Junguo, L Fantao. Internet of Things Technology and its Applications in Smart Grid. TELKOMNIKA Indonesian Journal of Electrical Engineering. 2014; 12(2): 940-946.

[10] Parallax. PING Ultrasonic Distance Sensor. 2013.

[11] K Prawiroredjo, N Asteria. Detektor Jarak Dengan Sensor Ultrasonic Berbasis Mikrokontroller. JETRI. $2008 ; 7$.

[12] R Hosamani, R Bagade. Arduino Based Water Billing System for Domestic Purpose. Internatinal Journal of Modern Trends in Engineering and Research. 2015; 2(6). 